\title{
PHILOSOPHICAL FUNDAMENTALS OF INCLUDING NATIONAL VALUES IN THE AESTHETIC CULTURE OF PERSONALITY IN THE PERIOD OF GLOBALIZATION
}

\author{
Gaybullaev Otabek Muhammadievich \\ Vice-Rector for Youth Affairs of Samakand State Institute of Foreign Languages \\ Doctor of Philosophy, Professor \\ gaybullayev@samdchti.uz \\ Samarkand, Uzbekistan \\ +998915221288
}

ANNOTATION: In today's era of globalization, the presence of national values in the aesthetic education of the individual is important. In the era of globalization, the inculcation of national values in the aesthetic culture of the individual as an integral feature of the spiritual culture of the Uzbek people is the ideology, worldview, and values of all nations and peoples living in the country. Raising the aesthetic culture of the individual in Uzbekistan is the core of the spiritual culture, morals, and psyche of all nations and peoples. This article describes the philosophical foundations of the inculcation of national values in the aesthetic culture of the individual.

KEYWORDS: Globalization, aesthetic education, national values, Action strategy, information attacks. Article Received: 10 August 2020, Revised: 25 October 2020, Accepted: 18 November 2020

I.Introduction. At a time of globalization, Uzbekistan is developing a national mentality based on national and universal values on the basis of spiritual reforms. Today, Uzbekistan, moving forward on the path of historical development, aims to rely on the ideas of the older generation in the development of its prosperous future through a healthy lifestyle, a moral and aesthetic culture of today's young generation.

In Uzbekistan, the development of national values inherent in the aesthetic culture of the individual has never been left out of the government's focus. "Understanding our national identity," Mirziyoyev said, "We must study the ancient and rich history of our country, strengthen research in this area, and fully support the work of scientists in the humanities."

The assessment of the past must be objective and, most importantly, free from various ideological views. "[1] Our society is creating innovative ideas in educating young people who strive for perfection on the basis of high respect for such creative people. We must not forget that in an era of rapid development, it is becoming increasingly important for all of us to have a sincere sense of nationalism.

Speaking about this, he emphasized the essence of national and universal characteristics: "Only as a head of state, first of all, as a child of our people with a great history, culture and spirituality, as human beings "[2] we must inculcate them in the minds and hearts of all.

II.Main part. In the era of globalization, the inculcation of national values in the aesthetic culture of the individual as an integral feature of the spiritual culture of the Uzbek people is the ideology, worldview, and values of all nations and peoples living in the country. Raising the aesthetic culture of the individual in Uzbekistan is the core of the spiritual culture, morals, and psyche of all nations and peoples. Because this process is constantly reflected in the pleasant relations between the nations of our country.

National values in society in terms of moral norms are based on the equality of nations and peoples, the principles of deep respect for people of other nationalities, their spiritual culture, traditions, national feelings. Today, the role of the spiritual heritage of our ancestors is of great importance in the further development of nationalism and humanity as a feature of the way of life of our people, enriching the spiritual culture of the individual in terms of content and scope of social ties between nations and peoples living in Uzbekistan. However, national and universal characteristics bring people closer to each other ideologically, politically, morally, aesthetically, religiously, and protect them from various forms of selfishness, localism, and nationalism.

Universality also requires an understanding of national identity as a feature of the Uzbek people's way of life. "The current state of affairs in the field of national development and interethnic relations in a multi-ethnic state shows that every nation, not only the economic, socio-political and cultural opportunities of the people but also the spiritual and spiritual potential of their relations with national development. the goal cannot be achieved in any related field "[3].

The philosophical worldview of young people in society is formed on the basis of the teachings of our ancestors and their attitude to 
reality. Therefore, as an expression of aesthetic culture, our ancestors have developed national and universal values. Thus, culture is not only a key factor in enriching the spiritual world of people, but also a means of educating the individual in the spirit of devotion to their homeland, love for their cultural heritage, and respect for other peoples, traditions, and customs of their cultures.

In the process of developing the aesthetic culture of the individual in society, we must see the national and universal values of our ancestors, which have been perfected for thousands of years and are transforming their dignity into examples of high spirituality at all levels of the education system. Arming the education system with "high spirituality", developing national and universal features of our spirituality in the hearts of the younger generation, enriching the history of their spiritual and moral development with the philosophical thinking and national outlook of great people is becoming a topical issue. The education system, reflecting the continuity of these processes, is making great strides for our people in each year of independence.

If such achievements of the Uzbek people penetrate into the minds and hearts of every person in the society, "they will learn to be careful with the sources of our national culture, to learn more about world culture, to live based on universal values, to see our traditional values in harmony with a modern democratic society. Only then will our people gain a deeper understanding of their national identity, achieve spiritual growth, and look to the future with a clear vision. "[4]

The issue of educating an independent thinker in Uzbekistan, reflecting the national features of the aesthetic culture of our people, we can see the deep roots of our past heritage, from the Avesta to the veins of the philosophy of the independence period. In this process, the aesthetic culture of society seeks to enrich our spiritual consciousness from the events that take place around us, to know the impact of reality on the human spiritual world. Such aesthetic activities include the creation of material and spiritual wealth, production and scientific achievements, family aesthetics, the education system, the study of universal cultures, leisure, and so on.

From time immemorial, the territory of Uzbekistan has enriched the aesthetic culture of the individual with our national language, religion, legends and myths, artistic and aesthetic monuments, enriched its image in various ways with masterpieces of philosophical thought. In the process of such development, the worldview in socio-economic systems has created a great difference between one country and another, leading to the diversity of national and universal features of spiritual culture. At the same time, the aesthetic culture of the individual has created ample opportunities for our people to understand their identity and respect their national values. As a result, national and universal values are rising at the same time, demonstrating their eternity and continuity to the whole world. We must preserve these values and pass them on to the next generation objectively and wisely.

In Uzbekistan, the issue of educating the individual in the spirit of national and universal values is an urgent socio-philosophical process, which creates all the conditions for the development of a new social environment, spiritual worldview, moral values. This process consists of the interrelationship, ratio, and dialectical unity of objective and subjective factors that take place directly in society. Because in society, a person strives for innovation as a result of seeing or hearing the values of natural and social existence, enjoying the inner experiences of society. As a result, the healthy social environment of the society is renewed and enriched with modern ideas due to the expansion of the spiritual world of a person who seeks to study the current issues and mysteries of life.

Our young people, working in harmony and equality with the peoples of the world, strive to bring a new look and appearance to the spiritual life of society, to inculcate national and universal values in our spirituality. We can also learn from the world media that this situation is becoming one of the most pressing problems of all nations in the new century.

Therefore, the task of educating our people to their independent thinking, time-tested national values, healthy outlook, independent will, rich spirituality, ready to strike at any ideological pressure, and spiritual threats is urgent. We all need to nurture the spiritual life of society in the spirit of future generations, to form in their hearts and minds a healthy lifestyle, respect for national and national values from childhood "so that there is no gap in the spiritual world" [5].

Countries and entities that pose spiritual threats as a result of globalization are using various means of influence. In this regard, for example, they use a variety of factors, such as 'mass culture', that have a strong impact on people's emotional and imaginative perceptions, aimed at undermining national and universal values.

Reforms in Uzbekistan include such a process as "Spiritual and cultural life, education, cultural heritage, historical experience, religious, moral, enlightenment views, lifestyle, colorful relationships, science, folk holidays, festivals, performances and customs, art, covers areas such as literature. The specific ethnic characteristics of the people, the nation, its contribution to world civilization are in fact measured by these spiritual and cultural values "[6]. 
In the context of such globalization, in the period of building a democratic civil society based on the rule of law, a real society should be aware of a masked "mass culture" that seeks to exert ideological and artistic pressure, contrary to a healthy lifestyle and legal culture. We need to be aware of the existence of a worldview aimed at changing the spiritual culture of the individual, forming a momentary beautiful and immoral life, the goal of which is to lose devotion to the nation, sense of homeland, historical process, ancestral heritage and teachings, based on ideological oppression.

Consequently, the formation of abilities in a person, the rise of etiquette, interest in learning about the environment, finding their place in life is not only the socio-philosophical basis but also the child's social ideals, worldview, and consciousness. If parents do not pay attention to the interests and aspirations of their children, changes in consciousness, spiritual and socio-ethical, religious needs, other ideas, aspirations, and intentions that cover these needs will have an impact. In order to establish mutual respect, morality, human relations, spiritual culture in the family, it is necessary, first of all, to improve the spiritual environment in every home, to humanize it.

If the family, which was established as the first society in the history of mankind, is strong, today's society, which is very complex and diverse, will be strong, and the strength and humanity of the society that the peace and prosperity of the country and people are stable. Only such a socio-political and moral-spiritual environment will become a key and objective factor in the development of a healthy lifestyle, high spiritual culture of society.

In building a civil society based on democratic principles, it is important to ensure that everyone has a high spiritual culture. Every person living in Uzbekistan is not indifferent to his sound mind, physical strength, spiritual depth, intellectual potential, political consciousness and, philosophical thinking. Because the "forces trying to exert spiritual pressure, first of all, to confuse our dearest, greatest wealth, our black-eyed youth under various guises, first of all, freedom of speech and thought, freedom of man and society, using modern methods. , tries to inculcate their ideology in their hardened minds, to put the values of the Farb above our millennial and sacred values. "[7]

The situation in the Far East, which is based on the doctrine of such absolute freedom, also directly creates a negative image of the spiritual life of society. We need to be careful that our young people imitate such a low-level "mass culture" without a national image. Every society seeks to inculcate these factors in the minds and hearts of the people in solving its economic, political and, social problems, in establishing new spiritual environments and processes, in transforming and implementing its spiritual culture into the worldview of the youth.

Unless the future of a country or a nation on the basis of globalization enjoys national values formed on the basis of creative ideas, such a landscape will remain in the form of gold reserves in the depths of the earth with its socio-historical significance and significance until it takes place in society. The healthy lifestyle of a society determines the vitality and practical significance of the dialectical relationship in society as it pursues certain goals of the individual based on ideals, theories, and, principles. Therefore, it is necessary to equip every young generation with a healthy environment in socio-political life, to involve them in creative work.

Enriching the attitude of our youth to national values with the issues of globalization, enriching them with pure oriental spiritual life, using the advanced achievements of world civilization and the best examples of the historical roots and intellectual wealth of our people opens up vast opportunities for educating a new generation.In $t$ he 21 st century, the unprecedented exchange of information is intensifying the processes of globalization, as a result of which every nation or state seeks to develop its own national values. Such a philosophical worldview has an impact on the development of the estate hectic culture of the individual in the formation of the cultural heritage and ideological views of Uzbekistan. This process has begun to show a new look at the aesthetic culture of the individual in Uzbekistan. Particular attention is paid to the upbringing of the younger generation in each family on the basis of high aesthetic ideals, ensuring that they grow up to be fully developed individuals. Such activity is directly related to the development of aesthetic culture, the care of families in society, the creation of a wide range of conditions for women's life and work, the protection of motherhood and childhood by the state.

One of the urgent tasks is to explain to the general public the strategy of action of Uzbekistan, the goals of the Uzbek people to build a great state, the essence of national values. In this process, the effective use of reforms in the education system is the task of today. In inculcating national values in the hearts of every person, especially our people, it is necessary to cover all spheres of public life, to use effective methods and means of education, propaganda and, agitation. Commenting on the connection of globalization with our social life, President Sh.M.Mirziyoev said: In order to develop our country at a stable and rapid pace, to further increase the effectiveness of ongoing reforms, we have developed an Action Strategy for the five priority areas of development of the Republic of Uzbekistan for 2017-2021. This 
strategy includes improving state and society building, ensuring the rule of law and reforming the judiciary, further developing and liberalizing the economy, developing the social sphere, ensuring security, interethnic harmony and, religious tolerance, and pursuing a well-thought-out, mutually beneficial and practical foreign policy. issues have been identified as the main directions of our development "[8].

In an informed society in the context of globalization, the inculcation of national values in the aesthetic culture of the individual is carried out through various forms of education. At the same time, it is necessary to form the aesthetic culture of the individual on the basis of national values on the basis of the following tasks:

Creation of a differential pedagogicalpsychological and scientific program of inculcation of national values in all educational institutions in accordance with the age of pupils and students;

Finding innovative ways of inculcating national values in the minds of students in the field of aesthetic culture, based on the strategy of action and the five initiatives, on this basis, the creation of mechanisms of continuous control in the system of continuing education;

in-depth integration of national ideas in curricula, textbooks and manuals in conjunction with globalization and the formation of pedagogical systems of distance learning;

strengthening the promotion of national values in educational institutions and neighborhoods in accordance with the information society, in particular, raising the ideological, ideological, moral education to the level of modern requirements for the formation of a high aesthetic personality culture;

It is necessary to form the skills of teachers in the information society in the educational institution and to deepen the knowledge of young people, to inculcate the ideas of the information age in their minds and hearts in the national spirit, based on national values, beliefs in our sacred religion.

It is especially important to connect the aesthetic culture of the individual with national values in connection with the media and the centers of public opinion, as well as to inculcate it in the minds of the younger generation. They are the process of spiritual-enlightenment reforms, the most effective means of quickly reflecting the problems in this area in various aspects of society. The media, which is the "fourth power", must open the door to a variety of views and approaches, to awaken people's awareness of the changes and changes in our lives, to act on the principles of objectivity and fairness.

III.Result and discussion. In an informed society, special attention should be paid to the mechanisms of the high level of aesthetic culture of the individual and thus increase the role of national values. "The acceleration of the process of globalization and the beginning of the formation of a global civilization in the twentieth century has changed the nature of world ideologies. The lack of a powerful ideology to replace them, and the change in geopolitical goals, exacerbated the negative impact of these ideas. In such conditions, only a nation that clearly defines its goals, understands its needs and interests, has its own beliefs, in short, forms its own national idea, will save its future and determine its future "[9]. The Uzbek people, formed as such a nation, is always ready to enrich the worldview of the individual with advanced technologies, self-awareness on the basis of various influences, respect for national values and, aesthetic culture in the future on the basis of its centuries-old national idea.

In the field of religion, which is the most delicate and complex today, it should be borne in mind, first of all, that religion is one of the pillars of spirituality and culture, that national ideas and ideologies develop at all times in harmony with religious views. By its very nature, religion inculcates the ideas of national ideology in the hearts and minds of our compatriots through such noble feelings as purity and kindness. Forming a healthy and moderate attitude towards our sacred religion is the most important ideological task in this regard. Traditions, ceremonies and holidays, formed over the centuries and passed down from generation to generation as an invaluable heritage, also play an important role in inculcating the basic ideas of national ideology in the minds of individuals.

In Uzbekistan, it is necessary to make full use of the unifying features of our traditions and customs. Along with the study and promotion of national traditions, it is necessary to pay special attention to the reduction of weddings, customs and, traditions, to avoid waste and luxury in this regard. To do this, first of all, it is necessary to pay special attention to the ongoing reforms in the country, to strengthen the individual's confidence in national values. These processes are accelerating year by year as a result of globalization, leading to the emergence of new ideas before humanity. In particular, the global significance of the processes that take place as a result of globalization and the positive problems of national development, the global integration of human development and society, the universalization of the practice of ideas is reflected in the concept of "globalization". The emergence of a new global outlook on the world, radical changes in the means of communication, new processes related to the flow of investment, the spread of universal technologies are the main factors of globalization. Its improvement, first of all, accelerated the socio-economic, political and, 
national-ethnic processes [10]. On this basis, we can say that national values allow a person to determine their essence, the ratio of personal and general interests, on this basis to determine the nature and goals of their life goals. National values are a spiritual factor that allows a person to understand personal, social, national identity. We are witnessing the period of national awakening in the process of independent development of Uzbekistan, the growing conflict between good and evil in the world at a time when we are restoring our cultural heritage, national traditions and, values.

In any society, the aesthetic culture of the individual is focused on meeting the spiritual needs of the people. It will be alive and impressive only if national traditions and way of life are taken into account. At the same time, in the process of globalization, the task of the individual to carry out reforms to form a new aesthetic culture is based on national values. Knowing the history of our ancestors and being aware of the ideas of the peoples of the world is a powerful tool to instill in the minds of every citizen a sense of respect for national ideas and values. Ireland is a great place of worship for each of us, on this basis, the ideological struggles in the information society and state-building system, various cultural and educational ties play an important role in increasing the role and importance of the pursuit of beauty and enjoyment of life.

Today, rapidly developing globalization is gaining an $\mathrm{n}$ meaning in the spirituality of every state, people, nation, or youth g generation. In the development of society, "just as every social phenomenon has its pros and cons, the process of globalization is no exception. At present, its extremely sharp and wide-ranging effects can be seen and felt in almost all areas. In particular, the strengthening of integration and cooperation between nations and peoples, the creation of facilities for foreign investment, capital and, goods, the free movement of labor, the creation of many new jobs, the rapid spread of modern communication and information technologies, scientific advances, The harmonization on a universal basis, the acquisition of a new quality of dialogue between civilizations, the increase in opportunities for mutual assistance in the event of environmental disasters - all this, of course, is achieved due to globalization "[11]. But along with such achievements, we must not forget that globalization poses a spiritual threat to the national ideas, values, ideology, beliefs, and, the heritage of some peoples. Especially in the mind of a person who is not ready for such globalization, as if it is a manifestation of aesthetic culture, it leads to the separation of families, the consolidation of values.

Therefore, one of the urgent tasks is to explain to the general public the strategy of the
Movement for Independent Development of Uzbekistan, the goals of the Uzbek people to build a great state, to convey to the members of our society the essence of globalization and its role in the aesthetic culture of youth.

In the context of globalization, the protection of the people from spiritual threats, especially the growing youth, and the inculcation of the ideals of goodness in their hearts are consistently carried out in all spheres of society. Commenting on the connection of globalization with our social life today, President Sh.M.Miriziyoev said, is important. Therefore, in my opinion, it is more important today than ever to preserve and enrich the resources that determine the spiritual world of man, the culture of nations. "[12]

The renewal of scientific and technical achievements, the increase in the speed of information acquisition, in turn, play an important role in enriching the individual's consciousness with secular and religious knowledge, as well as in diversifying the spiritual world. It is important to enrich in them the knowledge, skills, and, abilities necessary for today's social development with the moral views of our ancestors. It is also important that all the spiritual, enlightenment and religious events held in the country to increase the activity of the individual in the society pay special attention to the issues of peace, tranquility, national security, national development, up the singing of a young generation committed to national and universal values. In particular, the deep understanding of the national identity of our people, the enjoyment of historically formed sources of enlightenment, respect for religious values, their comprehensive study has become a topical issue today. The focus of the spiritual world of the youth on goodness forms universal views based on the avoidance of various destructive ideas, the avoidance of religious extremist currents and forces, the avoidance of terrorism, and the avoidance of egocentrism.

Independence has created ample opportunities for the Uzbek people to form the spiritual and cultural ties of the distant past in connection with aesthetic education and moral values. Each of us must deeply understand that it is our civic duty to uphold national values in society and take a philosophical approach to the issue as a vital fact. The Lily is a sacred place in the creation of a permanent and consistent system of aesthetic and moral education of the Uzbek people. That is why all the relations, values, and, traditions in society go to the family to a certain extent. As the family is a sacred stronghold for young people, it plays an important role in the health of the spiritual and ideological environment in society. The political stability, legal literacy, moral purity, religious tolerance, harm the only of national and 
universal values of the family, formed as the first part of such social life, are of special importance.

Today, the sharp increase in the number of different specialties in the world, in turn, creates ample opportunities to increase the level of general knowledge of the individual, to acquire the field and direction of their choice. There are many traditional, modern types and methods of education in there. For example, there are universal, national, spiritual, secular, moral, aesthetic, social, family, historical, religious, economic, spiritual, family, political, physical, ecological, sexual, military, patriotic, and so on. From there's expedient to understand that in the formation of the spirituality of the individual, other forms of upbringing are directly included in the structure of family upbringing.

The purpose of the educational activities carried out in Uzbekistan is to form a highly aesthetically educated person and a perfect person who is able to show examples of devotion in the way of respect for national values. The stronger a person's love for the family and respect for moral values, the stronger and more stable their need for spiritual maturity. At the same time, aesthetic and moral education is an important factor in the development of society.

That is why it is important to inculcate in the core of the national idea such as a sense of preservation and development of moral values, honest and clean work for the future of the Motherland, the pursuit of sophistication. Therefore, in strengthening the influence of national values on the aesthetic culture of the individual, it would be expedient to pay special attention to the following recommendations:

First, it is necessary to thoroughly study the philosophical foundations of the existence of an internal connection between the unique national mentality and lifestyle of each nation.

Secondly, it is necessary to deeply inculcate national values in a healthy lifestyle, with special emphasis on interethnic relations.

Third, we must bring up the individual in society in all respects, that is, both physically and mentally healthy. Because it is difficult to say that the counseling and law-enforcement mechanisms of more young adults are fully working in the field in strengthening the spiritual foundations of the family.

Fourth, in educating the individual aesthetically and morally, we must inculcate the customs, traditions, and way of thinking of the people. In this process, the teaching of humanity to be above all else, the development of such qualities as respect for other nations, other religions, love for the motherland, great respect for science and enlightenment, diligence will form a philosophical worldview that will serve as an example to others in the future.
Fifth, based on the geopolitical position of Uzbekistan in today's globalization process, it is necessary to establish the interaction of our children with citizens of foreign countries on the basis of deep philosophical observation.

IV.Conclusion. Religion is a national value that glorifies such a person and promotes his supremacy in the world. In the civil society being built in Uzbekistan, the role of globalization is great in the development of the individual with secular and religious knowledge, the formation of new aesthetic immunity, the education of the spiritual world with philosophical ideas, the ability to distinguish today from yesterday. We must all be vigilant in shaping the aesthetic immunity of young people in accordance with the requirements of the new age in accordance with national values, and in tasting its integration with the national idea. At the same time, it is the result of ongoing reforms to strengthen the aesthetic culture of the individual in accordance with national values, the formation of a free mind in relation to innovations in society, the determination of moral and aesthetic ideals in society. We must strengthen these high human feelings on the basis of aesthetic immunity. That is why we must fight for the formation of aesthetic immunity in the individual in connection with national values, for their sincere service to the destiny of the nation, the perpetuation of our country. Every citizen of Uzbekistan, who is interested in the future of the country, must wisely use all the opportunities and conditions created for a prosperous future and decide on the place of the national idea in our society on the basis of clear religious and secular knowledge. This, in turn, will serve as a basis for creating a world of beauty for future generations.

At a time when globalization is intensifying, we must all work tirelessly for the future not only of Uzbekistan but of the whole world. The Central Asian Cooperation Organization has also made a number of decisions in this regard. Therefore, raising the aesthetic culture of the individual in society ety should be a lesson for the young people who are the heirs of our future, everyone should understand that educating them on the basis of our national values is a matter of national importance.

\section{List of used literature:}

1.Address of the President of the Republic of Uzbekistan Shavkat Mirziyoyev to the Oliy Majlis. -T .: Uzbekistan, 2019. Page 40.

2 Karimov I.A. High spirituality is an invincible force. -T :S Spirituality, 2008. p.16.

3.Otamurotov Sadulla, Otamurotov Sarvar. Spiritual recovery in Uzbekistan. $\quad-\mathrm{T}$.: New Century Generation, 2003. p.92.

4 National ideaideas principles of spiritual development. -T .: Academy Publishing House, 
Publishing House of the National Society of Philosophers of Uzbekistan, 2005. Pages 24-25.

5. Karimov I.A. High spirituality is an invincible force. -T .: Manaviyat, 2008. 115- p.

6.Musaev F. Philosophical and legal bases of building a democratic state. T., Uzbekistan, 2007. 119 pages.

7. A free and prosperous life cannot be built without high spirituality. -T .: Uzbekistan, 2006. Page 27.

8. Mirziyoev Sh.M. The consent of our people is the highest value given to our activities. Volume 2 -T .: Uzbekistan, 2018. p.178.

9. Safoeva S. The impact of globalization on social life. // Political, philosophical, and, legal issues of democratization of society in the process of globalization. -T .: 2006. p.27.

10. Xo'janova T.J. Ideological prevention is a factor of ideological protection of the younger generation (socio-philosophical analysis). $-\mathrm{T}$.: National Society of Philosophers of Uzbekistan, 2019. Pages 66-67.

11. Karimov I.A. High spirituality is an invincible force. -Tashkent: Manaviyat, 2008, 111-112 pages.

12.Mirziyoev Sh.M. We will resolutely continue our path of national development and raise it to a new level. Volume $1-\mathrm{T}$.: Uzbekistan, 2018. Pages 29-30. 